University of Montana

ScholarWorks at University of Montana

\title{
Potential Site Productivity Influences the Rate of Forest Structural Development
}

\author{
Andrew J. Larson \\ University of Montana - Missoula, a.larson@umontana.edu \\ James A. Lutz \\ Rolf F. Gersonde \\ Jerry F. Franklin \\ Forest F. Hietpas
}

Follow this and additional works at: https://scholarworks.umt.edu/forest_pubs

Part of the Forest Management Commons

Let us know how access to this document benefits you.

\section{Recommended Citation}

Larson, Andrew J.; Lutz, James A.; Gersonde, Rolf F.; Franklin, Jerry F.; and Hietpas, Forest F., "Potential Site Productivity Influences the Rate of Forest Structural Development" (2008). Forest Management Faculty Publications. 27.

https://scholarworks.umt.edu/forest_pubs/27

This Article is brought to you for free and open access by the Forest Management at ScholarWorks at University of Montana. It has been accepted for inclusion in Forest Management Faculty Publications by an authorized administrator of ScholarWorks at University of Montana. For more information, please contact scholarworks@mso.umt.edu. 


\title{
POTENTIAL SITE PRODUCTIVITY INFLUENCES THE RATE OF FOREST STRUCTURAL DEVELOPMENT
}

\author{
Andrew J. Larson, ${ }^{1,3}$ James A. Lutz, ${ }^{1}$ Rolf F. Gersonde, ${ }^{2}$ Jerry F. Franklin, $^{1}$ and Forest F. Hietpas ${ }^{1}$ \\ ${ }^{1}$ College of Forest Resources, University of Washington, Box 352100, Seattle, Washington 98195-2100 USA \\ ${ }^{2}$ Watershed Services Division, Seattle Public Utilities, 19901 Cedar Falls Road SE, North Bend, Washington 98045 USA
}

\begin{abstract}
Development and maintenance of structurally complex forests in landscapes formerly managed for timber production is an increasingly common management objective. It has been postulated that the rate of forest structural development increases with site productivity. We tested this hypothesis for Douglas-fir (Pseudotsuga menziesii (Mirb.) Franco) forests using a network of permanent study plots established following complete timber harvest of the original old-growth forests. Forest structural development was assessed by comparing empirical measures of live tree structure to published values for Douglas-fir forests spanning a range of ages and structural conditions. The rate of forest structural development - resilience - exhibited a positive relationship with site index, a measure of potential site productivity. Density of shade-intolerant conifers declined in all study stands from an initial range of 336-4068 trees/ha to a range of 168-642 trees/ha at the most recent measurement. Angiosperm tree species declined from an initial range of 40-371 trees/ha to zero in seven of the nine plots in which they were present. Trends in shade-tolerant tree density were complex: density ranged from 0 to 575 trees/ha at the first measurement and was still highly variable (25-389 trees/ha) at the most recent measurement. Multivariate analysis identified the abundance of hardwood tree species as the strongest compositional trend apparent over the study period. However, structural variables showed a strong positive association with increasing shade-tolerant basal area and little or no association with abundance of hardwood species. Thus, while tree species succession and forest structural development occur contemporaneously, they are not equivalent processes, and their respective rates are not necessarily linearly related. The results of this study support the idea that silvicultural treatments to accelerate forest structural development should be concentrated on lower productivity sites when the management objective is reserve-wide coverage of structurally complex forests. Alternatively, high-productivity sites should be prioritized for restoration treatments when the management objective is to develop structurally complex forests on a portion of the landscape.
\end{abstract}

Key words: Douglas-fir; forest restoration; forest structural development; late-successional; productivity; Pseudotsuga menziesii; resilience; succession.

\section{INTRODUCTION}

Promoting the development of structurally complex forests is a primary strategy for conserving biodiversity in temperate forests (Lindenmayer and Franklin 2002, Lindenmayer et al. 2006) and an increasingly common management objective on public and some private lands (e.g., USDA and USDI 1994, City of Seattle 2000, Jenkins et al. 2004). Silvicultural treatments are one method used to promote the development of structural complexity in young, previously harvested forests (Carey 2003). Managers are faced with the challenge of prioritizing candidate forest stands for silvicultural treatment, in addition to designing site-specific treatments. Forest structure develops through a generally predictable sequence, gradually attaining complex con-

Manuscript received 19 July 2007; revised 5 December 2007; accepted 18 December 2007; final version received 8 January 2008. Corresponding Editor: J. A. Antos.

3 E-mail: a975764@u.washington.edu ditions many decades after high severity disturbance (Carey and Curtis 1996, Oliver and Larson 1996, Franklin and Van Pelt 2004, Spies 2004). Resilience describes the rate at which a community returns to predisturbance conditions (Halpern 1988); resilience is used here specifically with reference to the rate of forest structural development. Identifying factors that influence resilience of forests will help managers prioritize previously harvested forests for silvicultural treatments designed to accelerate the rate of forest structural development.

Understanding how development of community properties varies in response to changing abiotic or biotic context, such as a gradient of potential site productivity, is a promising line of investigation with the potential to increase the generality and predictive strength of community ecology (Agrawal et al. 2007). It has been postulated, but not empirically tested, that forests are more resilient-proceed through the structural development sequence faster-on high-productiv- 


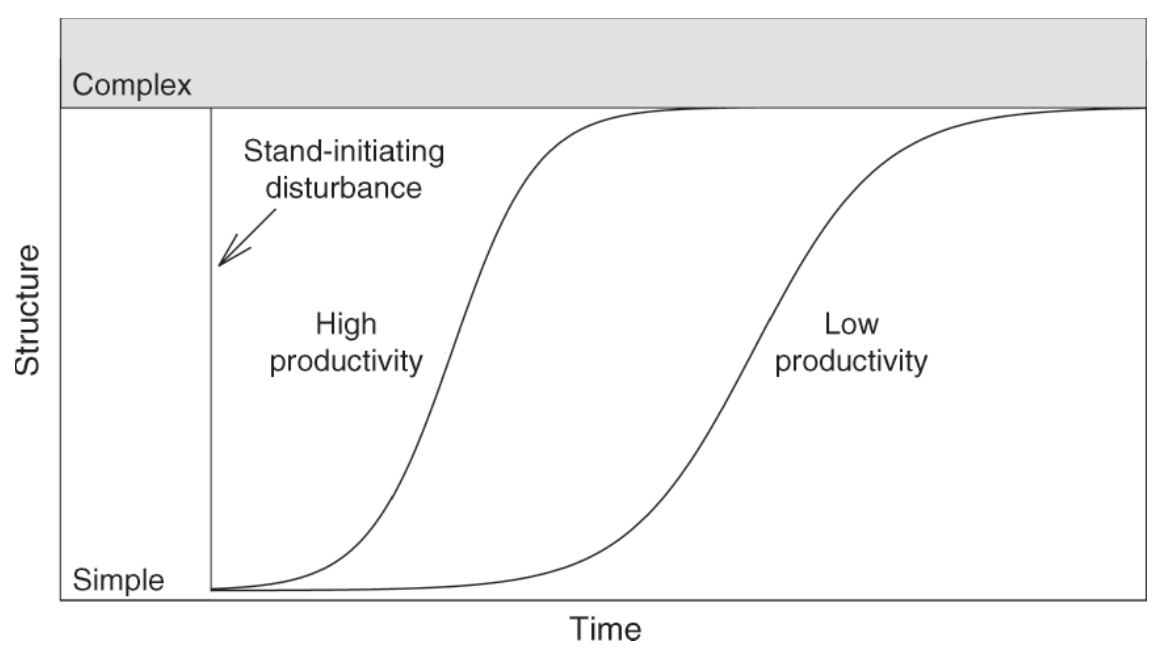

FIG. 1. Conceptual representation of the hypothesized relationship between forest structural development and site productivity. The postulated relationship is a specific case of the resilience-productivity hypothesis, which posits that resilience (defined here as the rate of forest structural development) will increase with productivity. We explicitly include anthropogenic disturbances, such as timber harvest, in this formulation of the resilience-productivity hypothesis.

ity sites (Franklin et al. 2002). This hypothesis is a specific case of the resilience-productivity hypothesis, which has seen few empirical tests (Steiner et al. 2006). Recent experimental work (Pringle et al. 2007) has caused some to suggest that low productivity ecosystems will be less able to respond to anthropogenic perturbation than their high productivity counterparts (Larson and Paine 2007). This adaptation of the resilienceproductivity hypothesis could contribute to the theoretical basis for applied and restoration ecology in forest ecosystems, if upheld by empirical studies.

Succession and structural development describe different aspects of change through time in ecological communities. Succession is the process of species composition change in an ecological community following disturbance (sensu Connell and Slatyer 1977). Structural development describes the changes in the sizes, abundance, and spatial arrangement of the various community elements (e.g., the live trees, snags, and logs in a forest) following a disturbance (Franklin et al. 2002). Successional change of species composition and structural development are not necessarily related. No succession of tree species occurs in single-species forest systems such as edaphic climax lodgepole pine (Pinus contorta var. murrayana (Grev. and Balf.) Engelm.) forests (Franklin and Dyrness 1988). However, structural development proceeds in lodgepole pine forests as trees establish, grow, decay, and die, as mediated by interactions with and between fire, fungi, and bark beetles (Gara et al. 1985, Stuart et al. 1989). Natural single-species forests are relatively rare; in most forest systems species succession and structural development occur contemporaneously and are related.

Based on the resilience-productivity hypothesis, the development of forest structure is predicted to occur at faster rates on high-productivity sites, given similar disturbance histories (Fig. 1). We used an unplanned experiment consisting of a set of permanent forest vegetation study plots in Douglas-fir (Pseudotsuga menziesii (Mirb.) Franco) forests spanning a gradient of potential site productivity to test this prediction. The permanent study plots document forest structural development following clearcut timber harvest of the original late-successional forest in the late 19th and early 20th centuries. There were three main objectives for this study: (1) conduct a test of the resilience-productivity hypothesis in the context of forest structural development; (2) characterize trends of and relationships between tree species succession and structural development; and (3) provide information that will be useful to forest managers, particularly those charged with managing for complex structure in previously harvested forests.

\section{Methods}

\section{Study area and field methods}

The study sites are a subset of a larger group of permanent study plots (PSP), originally established as a long-term forest growth and yield study (Table 1), located within the Cedar River Municipal Watershed (CRMW) in the central western Washington Cascade Range, USA $\left(47^{\circ} 24^{\prime} \mathrm{N}, 121^{\circ} 54^{\prime} \mathrm{W}\right)$. The original growth and yield study was designed to provide CRMW managers with an estimate of timber volume production in low elevation, second-growth Douglas-fir stands: permanent study plots were therefore located in stands spanning the productivity gradient present in the management area. The initiation of this study predates the widespread adoption of modern standards for experimental design in ecological studies: plots were subjectively located within study stands and plot sizes were determined according to the professional judgment of the responsible forester. The frequency and timing of 
TAble 1. Attributes of permanent study plots in the Cedar River Municipal Watershed, central western Washington, USA.

\begin{tabular}{|c|c|c|c|c|c|c|}
\hline Plot & $\begin{array}{l}\text { Size } \\
\left(\mathrm{m}^{2}\right)\end{array}$ & $\begin{array}{c}\text { Site } \\
\text { index† }(\mathrm{m})\end{array}$ & $\begin{array}{l}\text { Elevation } \\
(\mathrm{m})\end{array}$ & Year measured & Soil type & Soil texture \\
\hline PSP 2 & 4047 & 27 & 226 & $\begin{array}{l}1946,1953,1958,1974 \\
1979,1986,2005\end{array}$ & $\begin{array}{l}\text { sandy-skeletal, mixed, mesic } \\
\text { Typic Haplorthods }\end{array}$ & gravelly coarse sandy loam \\
\hline PSP 3 & 2023 & 24 & 486 & $\begin{array}{l}1953,1958,1964,1974 \\
1980,1986,2004\end{array}$ & $\begin{array}{l}\text { sandy-skeletal, mixed, mesic } \\
\text { Humid Haplorthods }\end{array}$ & sandy loam \\
\hline PSP 4 & 809 & 30 & 225 & $\begin{array}{l}1953,1958,1967,1974 \\
1982,1986,2005\end{array}$ & $\begin{array}{l}\text { sandy-skeletal, mixed, mesic } \\
\text { Typic Haplorthods }\end{array}$ & gravelly coarse sandy loam \\
\hline PSP 5 & 809 & 35 & 270 & $\begin{array}{l}1953,1967,1974,1979 \\
1986,2005\end{array}$ & $\begin{array}{l}\text { sandy-skeletal, mixed, mesic } \\
\text { Typic Haplorthods }\end{array}$ & gravelly coarse sandy loam \\
\hline PSP 7 & 1012 & 38 & 242 & $\begin{array}{l}1954,1967,1974,1979 \\
1986,2005\end{array}$ & $\begin{array}{l}\text { sandy-skeletal, mixed, mesic } \\
\text { Typic Haplorthods }\end{array}$ & gravelly coarse sandy loam \\
\hline PSP 8 & 1012 & 41 & 244 & $1954,1982,2005$ & $\begin{array}{l}\text { coarse-loamy, mixed, mesic, } \\
\text { ortstein Typic Haplorthods }\end{array}$ & gravely silt loam \\
\hline PSP 9 & 1012 & 42 & 509 & 1954, 1979, 1986, 2005 & $\begin{array}{l}\text { coarse-loamy, mixed, mesic, } \\
\text { ortstein Typic Haplorthods }\end{array}$ & gravely silt loam \\
\hline PSP 10 & 809 & 36 & 392 & $\begin{array}{l}1954,1967,1974,1986, \\
2003\end{array}$ & $\begin{array}{l}\text { sandy-skeletal, mixed, frigid } \\
\text { Typic Haplorthods }\end{array}$ & gravelly sandy loam \\
\hline PSP 11 & 1012 & 34 & 180 & $\begin{array}{l}1954,1974,1979,1986, \\
2005\end{array}$ & $\begin{array}{l}\text { sandy-skeletal, mixed, mesic } \\
\text { Typic Haplorthods }\end{array}$ & gravelly coarse sandy loam \\
\hline PSP 12 & 1012 & 42 & 177 & $\begin{array}{l}1954,1967,1974,1979 \\
\quad 1986,2003\end{array}$ & $\begin{array}{l}\text { sandy-skeletal, mixed, mesic } \\
\text { Typic Haplorthods }\end{array}$ & gravelly coarse sandy loam \\
\hline PSP 14 & 809 & 34 & 268 & $\begin{array}{l}1954,1974,1981,1986, \\
2006\end{array}$ & $\begin{array}{l}\text { coarse-loamy, mixed, mesic, } \\
\text { ortstein Typic Haplorthods }\end{array}$ & sandy loam \\
\hline PSP 16 & 809 & 34 & 294 & 1957, 1960, 1979, 2005 & $\begin{array}{l}\text { coarse-loamy, mixed, mesic, } \\
\text { ortstein Typic Haplorthods }\end{array}$ & sandy loam \\
\hline
\end{tabular}

$\dagger$ Base age 50 years at breast height (King 1966).

\$ Goldin (1992).

remeasurements was determined by the availability of CRMW staff and funding. We analyzed the $n=12$ plots (from a total of $n=21$ original plots) that had not experienced silvicultural manipulation since initiation of the post-harvest cohort. All plots except one regenerated naturally; in addition to abundant natural regeneration, PSP 3 was planted with Douglas-fir seedlings.

The study plots analyzed here are distributed along a $17.4 \mathrm{~km}$ reach of the east-west-oriented Cedar River valley and are located within the Tsuga heterophylla Zone, which is typified by dominance of the shadeintolerant conifer Douglas-fir in early-successional stages (Franklin and Dyrness 1988). The shade-tolerant conifer tree species western hemlock (Tsuga heterophylla (Raf.) Sarg.) and western red cedar (Thuja plicata Donn ex D. Don) become increasingly dominant in later successional stages (Franklin et al. 2002). The climate in the Cedar River valley is characterized by rainy, cool winters and moderate, dry summers (Barg and Edmonds 1999). Average annual precipitation is $1420 \mathrm{~mm}$, falling primarily as rain between October and May. The temperature regime is moderate: average annual, July and January temperatures are $9.7^{\circ}, 16.9^{\circ}$, and $3.2^{\circ} \mathrm{C}$, respectively.

Species and diameter at breast height (diameter in $\mathrm{cm}$ at $1.37 \mathrm{~m}$ above ground level; dbh) of all conifer trees present within study plots were recorded at each measurement. Diameter at breast height of all angiosperm (hardwood) trees was also measured, but species was not always recorded. The number of trees present in each PSP across all measurement periods ranged from 26 to 1935 stems per plot.
Site productivity was characterized with King's site index (King 1966). Site index was calculated using total height and age at breast height of canopy-dominant Douglas-fir; empirical age-height curves were used to determine the site index number, the height of dominant Douglas-fir at breast height age of 50 years. At least three trees were used to calculate site index for each PSP (maximum $n=7$ trees for PSP 2).

\section{Data analysis}

Forest structure was characterized from permanent plot records for each measurement period with the oldgrowth index $\left(I_{\mathrm{og}}\right)$, a composite measure of live tree variables (Acker et al. 1998). The variable $I_{\text {og }}$, which is positively related to structural complexity in Douglas-fir forests (Zenner 2004), subsumes the four live-tree overstory variables identified as successfully discriminating between young, mature, and old-growth Douglas-fir stands (Spies and Franklin 1991): standard deviation of dbh for all trees $>5 \mathrm{~cm}$ dbh; density of Douglas-fir $>100 \mathrm{~cm}$ dbh (trees/ha); mean dbh $(\mathrm{cm})$ for all trees $>5 \mathrm{~cm} \mathrm{dbh}$; and density of all trees $>5 \mathrm{~cm} \mathrm{dbh}$ (trees/ha). Increasing values of the first three $I_{\mathrm{og}}$ subscores are associated with increasing old-growth structure; whereas decreasing values of the density of trees $>5 \mathrm{~cm}$ dbh are associated with increasing oldgrowth structure. The $I_{\text {og }}$ used here incorporates a slight modification of the original form and is built on more tenable assumptions about the eventual endpoint of Douglas-fir forest structural development. Specifically, the original formulation of $I_{\mathrm{og}}$ is based on regional mean values for old-growth structural variables. Implicit in the 
original construction of $I_{\mathrm{og}}$ is the assumption that all forest stands converge to mean late-successional conditions. This assumption is not ideal: old-growth structure is by definition heterogeneous and many old-growth forests never achieve mean conditions. Therefore, we used the $95 \%$ confidence intervals (CI) for the regional values, rather than the mean values (Zenner 2004). $I_{\mathrm{og}}$ is calculated as

$$
I_{\text {og }}=25 \sum_{i}\left|\frac{x_{i}-x_{i, \text { young }}}{x_{i, \text { old }}-x_{i, \text { young }}}\right|
$$

where $x_{i}$ is the measured value for the $i$ th structural variable; $x_{i \text {,young }}$ is the regional mean value for the $i$ th structural variable in young Douglas-fir forests and $x_{i \text {,old }}$ is the lower bound (upper bound for density [no. trees/ha] of all trees $>5 \mathrm{~cm} \mathrm{dbh}$ ) of the $95 \%$ CI for the $i$ th structural variable in old-growth Douglas-fir forests. $I_{\mathrm{og}}$ is constrained to range from 0 to 100 (see Acker et al. 1998 for additional details); a score of 0 corresponds to typical young-forest structure while a score of 100 is interpreted as old-growth (complex) structure. In the formulation used here (Eq. 1), an $I_{\mathrm{og}}$ of 100 defines the minimum threshold for complex forest structure.

In order to compare resilience (i.e., the rate of forest structural development) of the different stands we fit a sigmoid curve (Spies and Franklin 1988) to the series of $I_{\text {og }}$ measurements for each permanent plot. We fit a model of the form

$$
I_{\mathrm{og}}=\frac{100}{1+\exp \left(-\left[t-t_{50}\right] / k\right)}
$$

where $t$ is stand age in years and $t_{50}$ and $k$ are parameters to be estimated. This particular form was desirable for several reasons. First, $t_{50}$ is interpreted directly as an estimate of resilience, the rate of recovery toward latesuccessional conditions: in this case, expressed as the time in years to reach $I_{\mathrm{og}}=50$. Because the lower limit of $I_{\mathrm{og}}$ is determined by stand structure associated with forests $40-80$ years old, it is expected that the $I_{\text {og }}$ vs. age curve will be asymptotic for very young ( $<40$ years) forests. Relative to the total duration of forest structural development (Franklin et al. 2002) rapid structural change occurs in the maturation stage (Acker et al. 1998), resulting in a steep increase in the $I_{\text {og }}$ vs. age curve, followed by the gradual attainment of structurally complex old-growth conditions. Even seemingly catastrophic disturbances do not necessarily remove all live tree elements of forest structure (Franklin and MacMahon 2000). Thus, a flexible model that could accommodate forest ecosystem response to incomplete disturbance - a model not constrained to pass through the origin - was necessary. Curves were fit to augmented $I_{\mathrm{og}}$ series which included an initial values of $I_{\mathrm{og}}=0$ at stand age 0 years for each plot. This addition is appropriate since the study sites were harvested com- pletely: no residual live trees from the original latesuccessional forest are apparent in the plot records.

Estimates of $t_{50}$ were obtained for $n=11$ plots $(P<$ $0.01)$. A nonzero $I_{\text {og }}$ score was attained at PSP 2 only in the most recent measurement period, which is insufficient to derive an estimate of $t_{50}$, thus PSP 2 could not be included in the productivity-resilience analysis. Visual examination of the data indicates that $t_{50}$ at PSP 2 (site index $[\mathrm{SI}]=27$ ) will be approximately 100 years, consistent with observed relationship between $t_{50}$ and SI for the remainder of the study plots (see Results).

Nonmetric multidimensional scaling (NMS) (Kruskal 1964) was used to characterize changes in species composition over successional time. Input variables for the NMS ordination of tree species composition were two measures of abundance (basal area $\left[\mathrm{m}^{2} /\right.$ ha] and stem density [no. trees/ha]) for angiosperm species, shadetolerant conifer species, and shade-intolerant species at each plot-year combination. Stem density and basal area together provide a more complete picture of tree species composition because stem density alone does not reflect the influence of tree size on stand-scale species composition. Sorensen's distance measure was used after data were relativized by column totals. The "slow and thorough" autopilot mode of PC-ORD version 5.0 (MjM Software Design, Gleneden Beach, Oregon, USA) in which 250 runs with the real data were analyzed for one- to six-dimensional solutions was used. A Monte Carlo test with 250 runs of randomized data indicated that the NMS ordination extracted stronger axes than expected by chance $(P<0.01)$. A final two-dimensional solution with a stress of 11.05 and instability of $1.0 \times$ $10^{-7}$ was selected after inspecting stress values at each dimension. Pearson correlation coefficients $(r)$ were used to characterize the relationship between the NMS axes (species-succession space) and a second matrix of structural variables comprised of the four input variables for $I_{\mathrm{og}}$, as well as the calculated $I_{\mathrm{og}}$ scores.

\section{RESUlTS}

The live tree component of forest structure developed increasing similarity to late-successional conditions on all plots over the period of observation. The density of live trees $>5 \mathrm{~cm}$ dbh declined, while mean and standard deviation of tree diameter increased (Table 2). The coefficient of variation of tree diameter increased in all but one stand, PSP 5, over the course of the study. Two stands (PSP 8 and PSP 12) also included large diameter Douglas-fir ( $>100 \mathrm{~cm} \mathrm{dbh})$ by the last measurement. As of the most recent measurement $I_{\mathrm{og}}$ scores ranged from 20.2 to 88.0 (Fig. 2). The parameter $t_{50}$ decreased with increasing site productivity (Fig. 3, adjusted correlation $\left.\left[r_{\text {adj }}^{2}\right]=0.32, F_{1,9}=5.73, P=0.04\right)$, marking a relationship between resilience and productivity.

The four component variables of $I_{\mathrm{og}}$ did not increase uniformly during forest structural development (Fig. 4). Mean tree dbh drove initial increases in $I_{\text {og }}$ values. Total 
TABLE 2. Developmental trends of live tree structural variables in previously harvested Douglas-fir forests located in the Cedar River Municipal Watershed, western Washington Cascade Range, USA.

\begin{tabular}{|c|c|c|c|}
\hline \multirow{3}{*}{$\begin{array}{l}\text { Site and stand } \\
\text { age (years) }\end{array}$} & \multirow{2}{*}{$\begin{array}{l}\text { dbh of all trees } \\
>5 \mathrm{~cm} \text { dbh }(\mathrm{cm})\end{array}$} & \multicolumn{2}{|c|}{$\begin{array}{l}\text { Tree density } \\
\text { (no./ha) }\end{array}$} \\
\hline & & All trees & \\
\hline & Mean & $>5 \mathrm{~cm} \mathrm{dbh}$ & $>100 \mathrm{~cm} \mathrm{db}$ \\
\hline
\end{tabular}

\begin{tabular}{|c|c|c|c|c|}
\hline PSP 2 & & & & \\
\hline $\begin{array}{l}24 \\
31 \\
36 \\
52 \\
57 \\
64 \\
83\end{array}$ & $\begin{array}{c}7.3 \\
9.2 \\
10.9 \\
16.2 \\
17.9 \\
20.0 \\
20.8\end{array}$ & $\begin{array}{c}2.5 \\
3.7 \\
4.2 \\
5.5 \\
6.2 \\
7.1 \\
12.1\end{array}$ & $\begin{array}{c}4779 \\
4545 \\
3475 \\
1934 \\
1687 \\
1368 \\
595\end{array}$ & $\begin{array}{l}0 \\
0 \\
0 \\
0 \\
0 \\
0 \\
0\end{array}$ \\
\hline $\begin{array}{c}\text { PSP } 3 \\
28 \\
33 \\
39 \\
49 \\
55 \\
61 \\
79\end{array}$ & $\begin{array}{l}13.6 \\
15.4 \\
17.1 \\
21.9 \\
25.0 \\
27.3 \\
27.7\end{array}$ & $\begin{array}{c}5.4 \\
6.7 \\
8.3 \\
9.0 \\
9.9 \\
11.2 \\
16.3\end{array}$ & $\begin{array}{c}2100 \\
1970 \\
1775 \\
1270 \\
1055 \\
950 \\
935\end{array}$ & $\begin{array}{l}0 \\
0 \\
0 \\
0 \\
0 \\
0 \\
0\end{array}$ \\
\hline $\begin{array}{c}\text { PSP } 4 \\
21 \\
26 \\
35 \\
42 \\
50 \\
54 \\
73\end{array}$ & $\begin{array}{l}13.9 \\
16.3 \\
19.9 \\
23.5 \\
25.4 \\
27.2 \\
29.6\end{array}$ & $\begin{array}{c}3.4 \\
3.9 \\
5.6 \\
6.0 \\
6.3 \\
6.9 \\
11.8\end{array}$ & $\begin{array}{c}1247 \\
1247 \\
1309 \\
1186 \\
1074 \\
790 \\
692\end{array}$ & $\begin{array}{l}0 \\
0 \\
0 \\
0 \\
0 \\
0 \\
0\end{array}$ \\
\hline $\begin{array}{c}\text { PSP } 5 \\
30 \\
44 \\
51 \\
56 \\
63 \\
82\end{array}$ & $\begin{array}{l}18.9 \\
27.3 \\
29.2 \\
31.7 \\
33.5 \\
41.4\end{array}$ & $\begin{array}{c}8.1 \\
8.5 \\
9.5 \\
8.9 \\
9.7 \\
10.2\end{array}$ & $\begin{array}{c}1186 \\
865 \\
729 \\
716 \\
655 \\
457\end{array}$ & $\begin{array}{l}0 \\
0 \\
0 \\
0 \\
0 \\
0\end{array}$ \\
\hline $\begin{array}{c}\text { PSP } 7 \\
41 \\
54 \\
61 \\
66 \\
73 \\
92\end{array}$ & $\begin{array}{l}26.1 \\
30.7 \\
32.9 \\
36.2 \\
37.9 \\
38.5\end{array}$ & $\begin{array}{c}8.7 \\
11.7 \\
13.6 \\
13.5 \\
17.1 \\
22.5\end{array}$ & $\begin{array}{l}850 \\
642 \\
524 \\
484 \\
484 \\
445\end{array}$ & $\begin{array}{l}0 \\
0 \\
0 \\
0 \\
0 \\
0\end{array}$ \\
\hline $\begin{array}{c}\text { PSP } 8 \\
61 \\
89 \\
112\end{array}$ & $\begin{array}{l}40.3 \\
50.1 \\
31.6\end{array}$ & $\begin{array}{l}13.1 \\
17.8 \\
29.0\end{array}$ & $\begin{array}{l}514 \\
336 \\
524\end{array}$ & $\begin{array}{c}0 \\
0 \\
10\end{array}$ \\
\hline $\begin{array}{c}\text { PSP } 9 \\
44 \\
69 \\
95\end{array}$ & $\begin{array}{l}34.8 \\
45.5 \\
57.1\end{array}$ & $\begin{array}{l}13.2 \\
20.6 \\
23.5\end{array}$ & $\begin{array}{l}337 \\
338 \\
257\end{array}$ & $\begin{array}{l}0 \\
0 \\
0\end{array}$ \\
\hline $\begin{array}{c}\text { PSP } 10 \\
27 \\
40 \\
47 \\
59 \\
76\end{array}$ & $\begin{array}{l}17.1 \\
22.9 \\
28.1 \\
29.2 \\
33.2\end{array}$ & $\begin{array}{c}6.6 \\
10.2 \\
12.1 \\
15.2 \\
17.5\end{array}$ & $\begin{array}{c}1494 \\
1210 \\
976 \\
790 \\
630\end{array}$ & $\begin{array}{l}0 \\
0 \\
0 \\
0 \\
0\end{array}$ \\
\hline $\begin{array}{c}\text { PSP } 11 \\
81 \\
101 \\
106 \\
113 \\
132\end{array}$ & $\begin{array}{l}34.9 \\
30.7 \\
33.2 \\
32.1 \\
36.6\end{array}$ & $\begin{array}{l}11.3 \\
18.2 \\
17.8 \\
20.4 \\
22.8\end{array}$ & $\begin{array}{l}603 \\
850 \\
692 \\
632 \\
504\end{array}$ & $\begin{array}{l}0 \\
0 \\
0 \\
0 \\
0\end{array}$ \\
\hline
\end{tabular}

TABle 2. Continued

\begin{tabular}{|c|c|c|c|c|}
\hline \multirow{3}{*}{$\begin{array}{l}\text { Site and stand } \\
\text { age (years) }\end{array}$} & \multirow{2}{*}{\multicolumn{2}{|c|}{$\begin{array}{l}\text { dbh of all trees } \\
>5 \mathrm{~cm} \mathrm{dbh}(\mathrm{cm})\end{array}$}} & \multicolumn{2}{|c|}{$\begin{array}{l}\text { Tree density } \\
\text { (no./ha) }\end{array}$} \\
\hline & & & \multirow{2}{*}{$\begin{array}{l}\text { All trees } \\
>5 \mathrm{~cm} \mathrm{dbh}\end{array}$} & \multirow{2}{*}{$\begin{array}{r}\text { Douglas-fir } \\
>100 \mathrm{~cm} \mathrm{dbh}\end{array}$} \\
\hline & Mean & SD & & \\
\hline \multicolumn{5}{|l|}{ PSP 12} \\
\hline 48 & 33.5 & 9.7 & 672 & 0 \\
\hline 61 & 26.9 & 15.3 & 850 & 0 \\
\hline 68 & 33.6 & 16.4 & 583 & 0 \\
\hline 73 & 30.8 & 19.3 & 751 & 0 \\
\hline 80 & 28.2 & 20.1 & 662 & 0 \\
\hline 97 & 38.4 & 25.2 & 553 & 10 \\
\hline \multicolumn{5}{|l|}{ PSP 14} \\
\hline 27 & 13.2 & 5.8 & 3038 & 0 \\
\hline 47 & 20.8 & 8.4 & 1494 & 0 \\
\hline 54 & 22.8 & 9.5 & 1266 & 0 \\
\hline 59 & 24.1 & 10.9 & 976 & 0 \\
\hline 79 & 25.5 & 15.5 & 852 & 0 \\
\hline \multicolumn{5}{|l|}{ PSP 16} \\
\hline 22 & 14.4 & 5.7 & 2174 & 0 \\
\hline 25 & 16.6 & 6.0 & 1840 & 0 \\
\hline 44 & 25.0 & 8.3 & 963 & 0 \\
\hline 70 & 29.1 & 15.8 & 778 & 0 \\
\hline
\end{tabular}

tree density and standard deviation of tree $\mathrm{dbh}$ corresponded with subsequent increases in $I_{\text {og }}$ scores. Large diameter trees contributed to increases in $I_{\text {og }}$ only at relatively high $I_{\mathrm{og}}$ scores.

A successional trend in tree species composition emerged over the duration of the study. Density of shade-intolerant conifer species (Douglas-fir, Sitka spruce [Picea sitchensis (Bongard) Carrière], noble fir [Abies procera Rehd.], and western white pine [Pinus monticola Douglas ex D. Don]) declined in all plots over the period of study from an initial range of 336-4068 trees/ha (mean 1382 trees/ha) to a range of 168-642 trees/ha (mean 373 trees/ha) at the most recent measurement (Fig. 5). Angiosperm trees occurred in nine of the 12 study stands. Density of angiosperm trees (bitter cherry [Prunus emarginata (Dougl. Ex Hook.) D. Diert.], red alder [Alnus rubra Bong.], willow [Salix sp.], and bigleaf maple [Acer macrophyllum Pursh]) declined from an initial range of 40-371 trees/ha (mean 123 trees/ha) to zero in seven of the nine plots in which they were present. However, PSP 10 and PSP 11 contained small amounts of bigleaf maple at the most recent measurement: 12.4 trees/ha at stand age 76 and 19.9 trees/ha at 132 years, respectively. The shade-tolerant conifer component (western hemlock, western redcedar, and Pacific silver fir [Abies amabilis Dougl. Ex Forbes]) exhibited complex dynamics across the study stands (Fig. 6). Shade-tolerant tree density at the initial measurement varied from 0 to 575 trees/ha (mean 151 trees/ha). By the most recent measurement shadetolerant tree density ranged from 25 to 389 trees/ha (mean 226 trees/ha). A single stand (PSP 5) has supported very low densities of shade-tolerant trees 


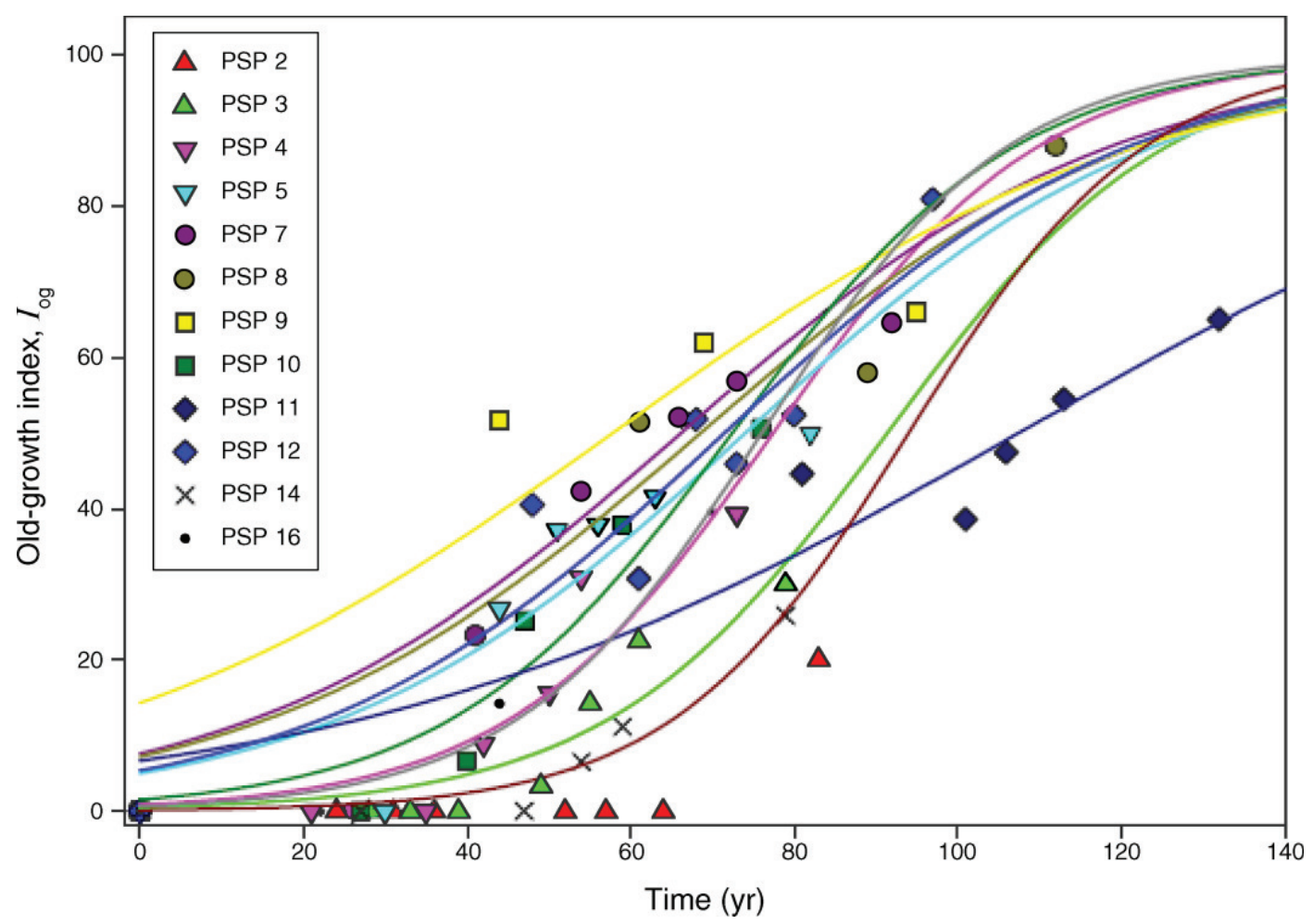

FIG. 2. Developmental trajectory of forest structure as measured by the old-growth index $\left(I_{\mathrm{og}}\right)$ for permanent sample plots $(n=$ 12 plots) and fitted curves ( $n=11$ plots; see Eq. 2). The old-growth index is a unitless composite index based on four measures of live-tree forest structure: standard deviation of dbh for all trees $>5 \mathrm{~cm} \mathrm{dbh}$; density of Douglas-fir $>100 \mathrm{~cm} \mathrm{dbh}$ (no. trees/ha); mean $\mathrm{dbh}(\mathrm{cm})$ for all trees $>5 \mathrm{~cm} \mathrm{dbh}$; and density of all trees $>5 \mathrm{~cm}$ dbh (no. trees/ha). The old-growth index is scaled from 0 to 100 , with the lower and upper bounds corresponding to published values for regional mean young and old-growth live-tree forest structure variables. See Methods for additional detail on the calculation of the old-growth index.

and experienced virtually no net change over the study period.

The final two-dimensional NMS solution (Fig. 7) accounted for $93 \%$ of the variance in tree species composition based on the coefficient of determination between the distance in ordination space and distance in the original space for axis $1\left(r^{2}=0.60\right)$ and axis two $\left(r^{2}=\right.$ $0.33)$. The gradient represented by axis 1 was primarily driven by hardwood basal area $(r=-0.86)$ and stem density $(r=-0.77)$. Axis one was less strongly but negatively related to stem density $(r=-0.43)$ and basal area $(r=-0.11)$ of shade-tolerant conifers. Stem density and basal area of shade-intolerant conifers showed divergent patterns of association with axis 1: shadeintolerant conifer stem density $(r=-0.36)$ and basal area $(r=0.33)$ were weakly correlated with axis 1 . Axis 2 was driven primarily by the basal area of shade-tolerant conifers, which was positively related $(r=0.83)$, and stem density of shade-intolerant conifers, which showed a negative relationship $(r=-0.61)$. Angiosperm stem density $(r=-0.37)$ and basal area $(r=-0.24)$ exhibited weak negative relationships with axis 2 , while shadeintolerant conifer basal area $(r=0.41)$ and shadetolerant conifer stem density $(r=0.45)$ showed slightly stronger positive relationships with axis 2 .
Forest structure variables exhibited the strongest correlations with axis 2 (Fig. 7). Late-successional forest structure, as measured by $I_{\mathrm{og}}$, was positively correlated with axis $2(r=0.79)$. The mean and standard deviation of tree diameter had positive correlations of similar strength with axis $2: r=0.75$ and $r=0.83$, respectively. Density of all trees $>5 \mathrm{~cm}$ dbh was negatively correlated with both axis $2(r=-0.52)$ and axis $1(r=-0.45)$. Density of trees $>100 \mathrm{~cm}$ dbh was weakly correlated with axis $2(r=0.24)$ and not related to axis $1(r=0.01)$.

\section{DisCUSSION}

High-productivity sites developed toward complex structure more rapidly than low-productivity sites following stand-initiating disturbance in this study, supporting the resilience-productivity hypothesis (Franklin et al. 2002). The proposition that lowproductivity ecosystems will be slower to recover from anthropogenic perturbation relative to their high-productivity analogues (Larson and Paine 2007) is also supported, given that the study stands originated from timber harvest.

Tree growth and demographic processes both operate throughout forest structural development. However, the nonuniform increase of the component $I_{\text {og }}$ subscores suggests an underlying structure in the contributions of 


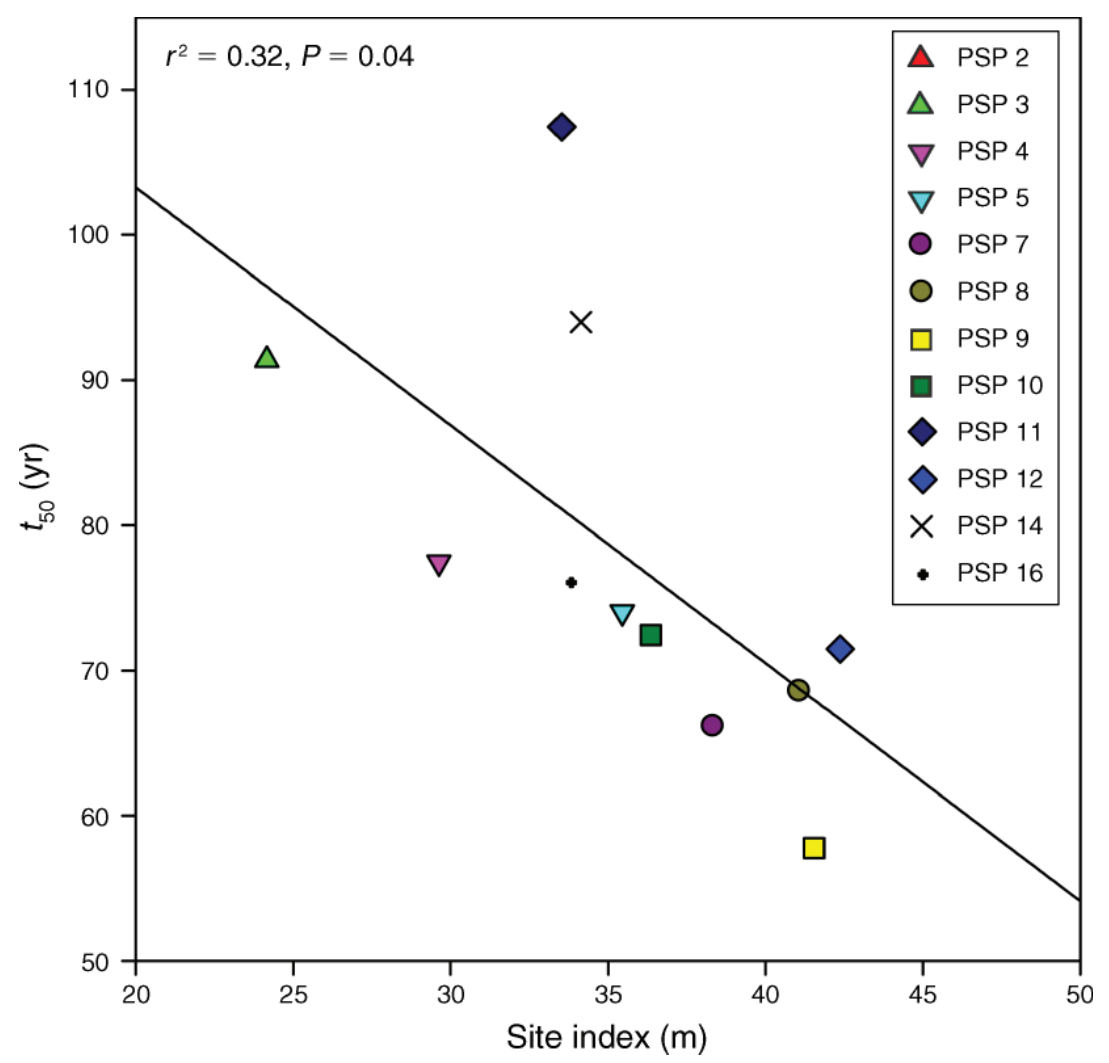

FIG. 3. Regression of time in years to reach $I_{\mathrm{og}}=50\left(t_{50}\right)$ on site index, a measure of site productivity. Site index corresponds to the total height $(\mathrm{m})$ of dominant Douglas-fir trees at breast height age of 50 years. Age at breast height and total height of dominant Douglas-fir trees were compared with the empirical age-height curves (King 1966) to determine the site index number for individual study plots. Forest resilience is measured by $t_{50}$, an estimate of which is provided as a parameter of the fitted logistic growth curve for each study plot (see Methods). Lower values of $t_{50}$ correspond to greater resilience.

different processes throughout the structural development sequence: tree growth dominates initially, followed by demographic processes, with the importance of tree growth reemerging later in stand development. The early contribution of the mean tree dbh subscore to the total $I_{\text {og }}$ score (Fig. 4) indicates that tree growth initially drives the development of forest structure. As mean tree size increases, competitive tree mortality reduces the density of the initial tree cohort, as reflected by the $I_{\mathrm{og}}$ subscore for density of trees $>5 \mathrm{~cm}$ dbh (Fig. 4). Noncompetitive mortality (e.g., due to wind, insects, or pathogens) removes members of the initial cohort during and after the self-thinning phase of stand development (Bible 2001, Lutz and Halpern 2006), providing growing space for shade-tolerant species to recruit (Franklin et al. 2002) and grow (Winter et al. 2002) in the understory, which increases the standard deviation of tree dbh (Fig. 4). The role of competitive and noncompetitive tree mortality and shade-tolerant conifer recruitment underscore the importance of demographic processes - tree mortality and recruitment - during intermediate stages of structural development. The late emergence of the trees $>100 \mathrm{~cm}$ dbh subscore (Fig. 4) illustrates that growth processes are important throughout the developmental sequence, not just in the early stages. Other studies have documented similar trends in forest structural development. Acker et al. (1998) found that the density of trees $>5 \mathrm{~cm}$ dbh and mean tree $\mathrm{dbh}$ approached old-growth values relatively quickly, while the standard deviation of tree $\mathrm{dbh}$ and density of trees $>100 \mathrm{~cm} \mathrm{dbh}$ attained old-growth values later in stand development. Zenner (2004) concluded that structural complexity in old Douglas-fir stands was primarily driven by the standard deviation of tree dbh and density of trees $>100 \mathrm{~cm} \mathrm{dbh}$.

The strongest successional signal detected in this study was the decline of hardwood tree abundance (Fig. 7). Interestingly, abundance of hardwood species showed little relationship to the development of forest structure. This result contrasts with that of Deal et al. (2004) who concluded that mixed conifer-alder stands are more structurally heterogeneous than pure conifer stands of the same age. It may be that the lack of a relationship between hardwood tree abundance and forest structural development in this present study is due to the relatively low abundance of hardwood trees in the study stands. The lack of a relationship between NMS axis one and forest structural complexity confirms that succession and structural development are not equivalent processes.

Variables representing increasing structural complexity were positively correlated with the second NMS axis, 


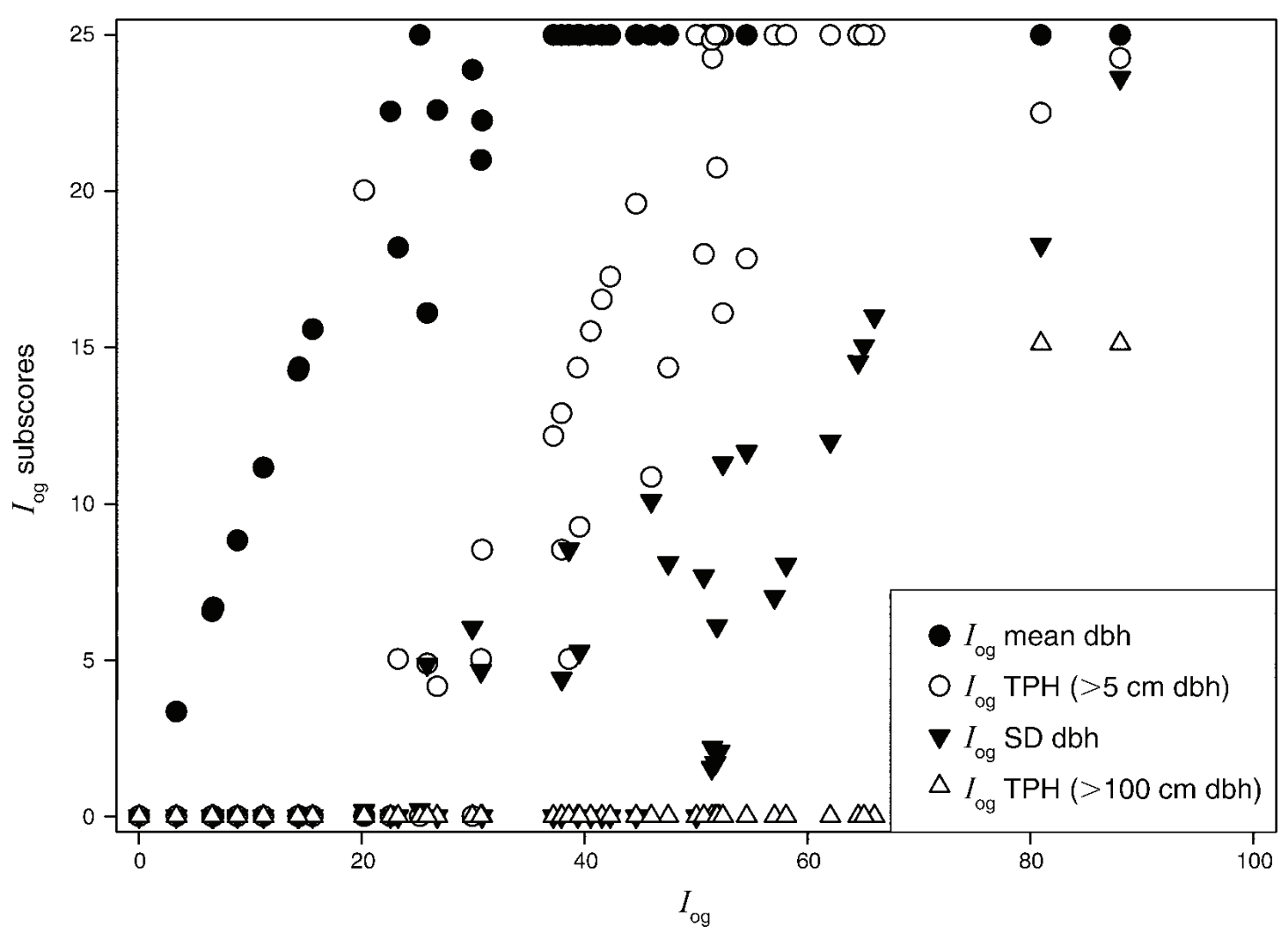

FIG. 4. The individual components of $I_{\mathrm{og}}$ each have their period of maximum change during different periods of forest development. The mean dbh subscore is responsible for generating most of the initial nonzero $I_{\mathrm{og}}$ values. The subscores for density of trees $>5 \mathrm{~cm}$ dbh (TPH, number of trees per hectare), standard deviation of dbh, and density (TPH) of trees $>100 \mathrm{~cm}$ dbh contribute to $I_{\mathrm{og}}$ at increasingly later stages of stand structural development, respectively.

the gradient of which was most strongly correlated with basal area of shade-tolerant conifers (Fig. 7). Density of shade-tolerant conifers, however, showed only a moderate positive correlation with axis two. Structural development of Douglas-fir forests occurs concurrent with the increasing abundance of shade-tolerant conifers, primarily western hemlock and western redcedar, as succession advances (Franklin and Hemstrom 1981, Huff 1995, Franklin et al. 2002, Van Pelt and Nadkarni 2004, Keeton and Franklin 2005, Zenner 2005). However, shade-tolerant conifers are not restricted to a latesuccessional role. They are often present in the standinitiating cohort (Isaac 1943, Franklin and Hemstrom 1981, Huff 1995, Larson and Franklin 2005, Lutz and Halpern 2006); structurally simple young forest stands can include hundreds of shade-tolerant conifers per hectare (Fig. 6). Structurally complex older forests are distinguished by the presence of large $(>40 \mathrm{~cm} \mathrm{dbh})$ individual shade-tolerant conifers (Franklin and Spies 1991, Acker et al. 1998), consistent with the positive correlation of forest structure variables with NMS axis two.

The association of the variables contributing to $I_{\mathrm{og}}$, and $I_{\mathrm{og}}$ itself with NMS axis two emphasize the necessary distinction between tree species succession and structural development. While succession and structural development occur contemporaneously, the rates of development between the two are not linearly related and the relationships vary throughout stand development. Here, the loss of three hardwood tree species during succession had little relationship to forest structural development.

Development of structural complexity in Douglas-fir forests requires mortality in the pioneering cohort and recruitment of shade-tolerant conifer species into the lower and middle canopy (Franklin et al. 2002, Zenner 2005). We hypothesize that the observed positive influence of potential site productivity on the rate of forest structural development is in part due to elevated rates of tree population processes-mortality and recruitment - in forests situated on high productivity sites.

Competition-based tree mortality should be positively related to the rate of structural development. The pioneer cohort develops towards a lower number of large individuals during the self-thinning stage of forest structural development (Oliver and Larson 1996, Franklin et al. 2002), creating higher values of $I_{\mathrm{og}}$ by both reducing stand density and increasing mean tree diameter (Fig. 4). Elevated rates of competitive mortality on more productive sites have been demonstrated (Yoda et al. 1963, Morris and Myerscough 1991) and 


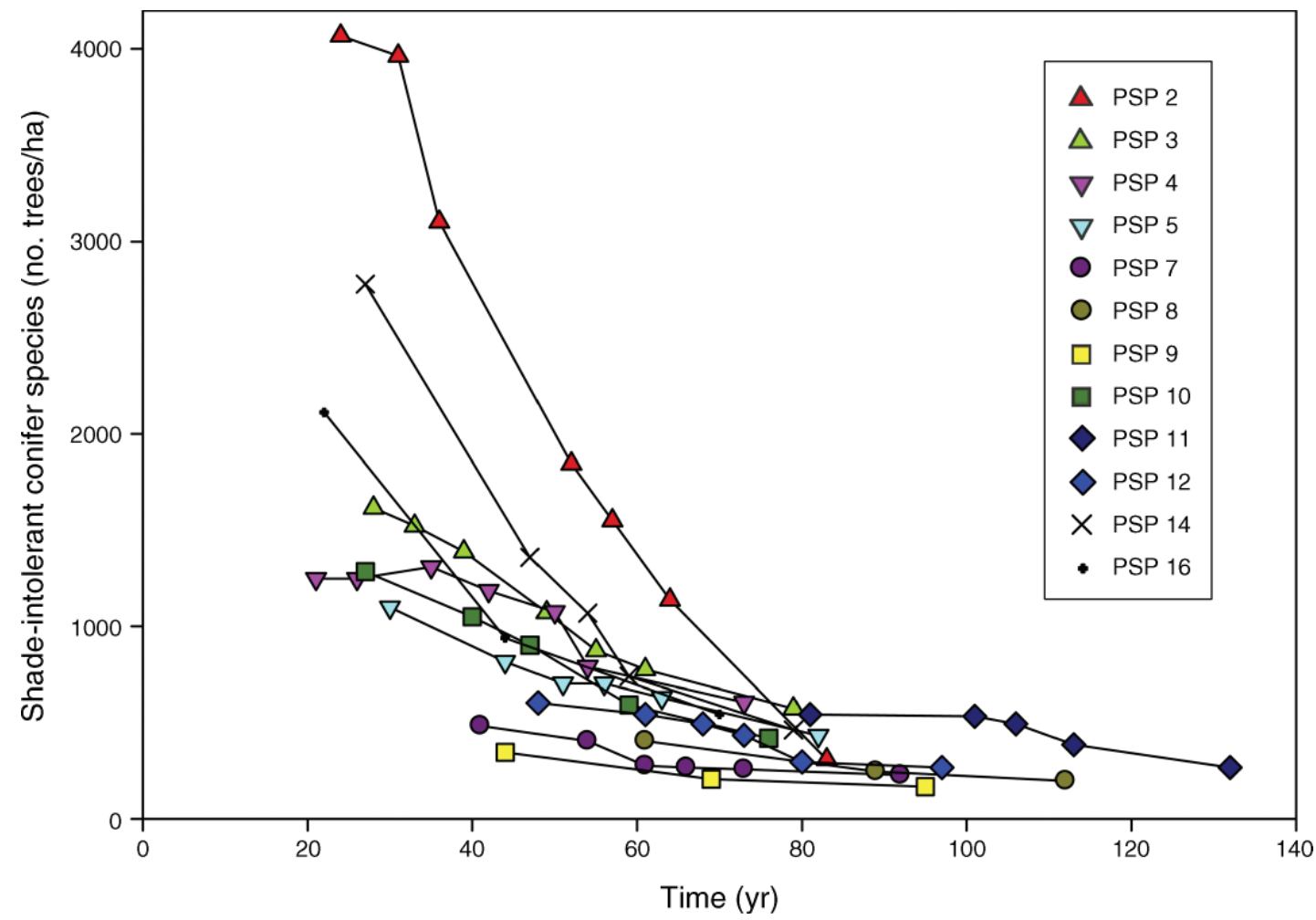

FIG. 5. Changes in density of shade-intolerant conifers (pooled for Douglas-fir, noble fir, Sitka spruce, and western white pine) over time.

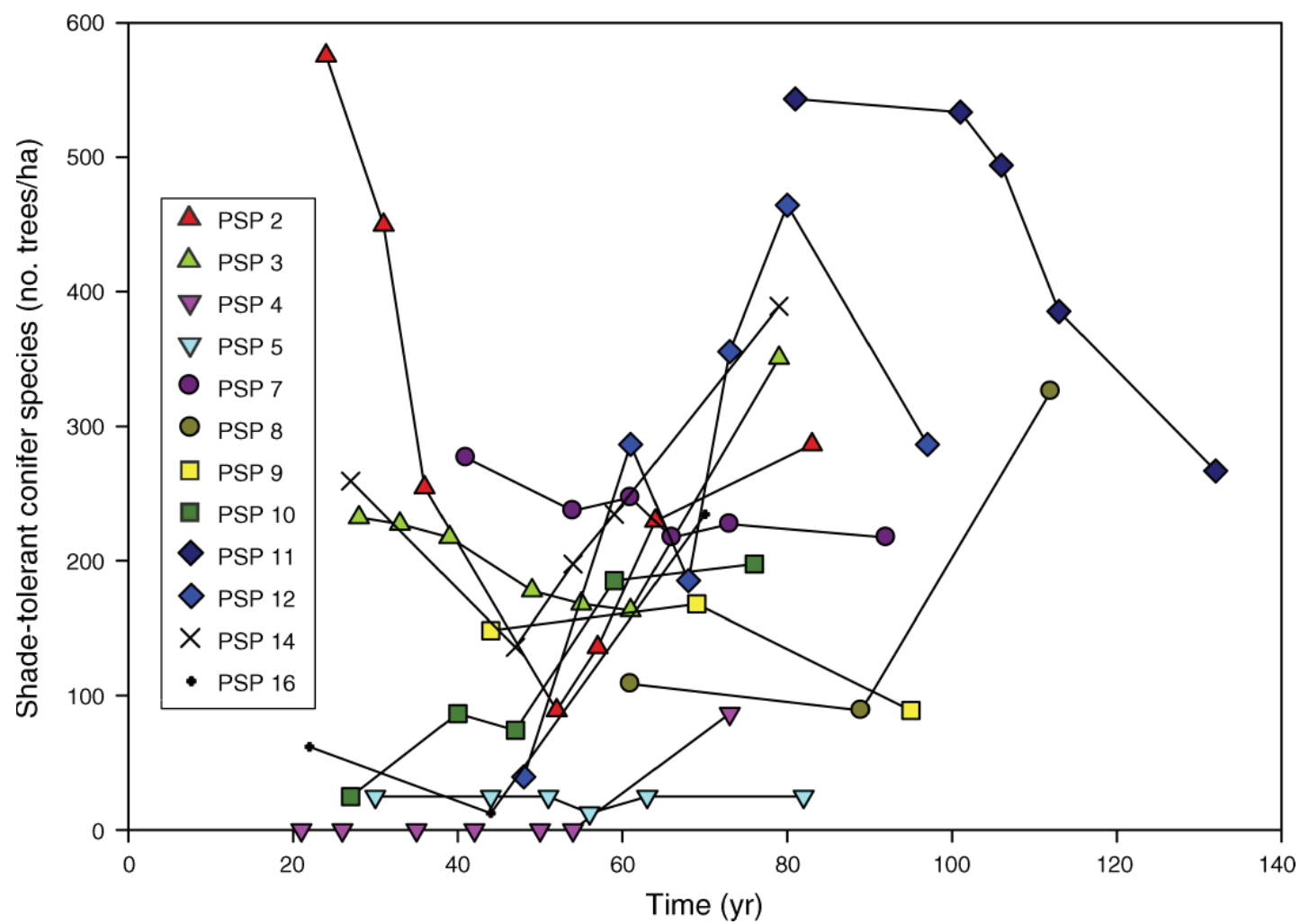

FIG. 6. Changes in density of shade-tolerant conifers (pooled for western hemlock, western redcedar, and Pacific silver fir) over time. 


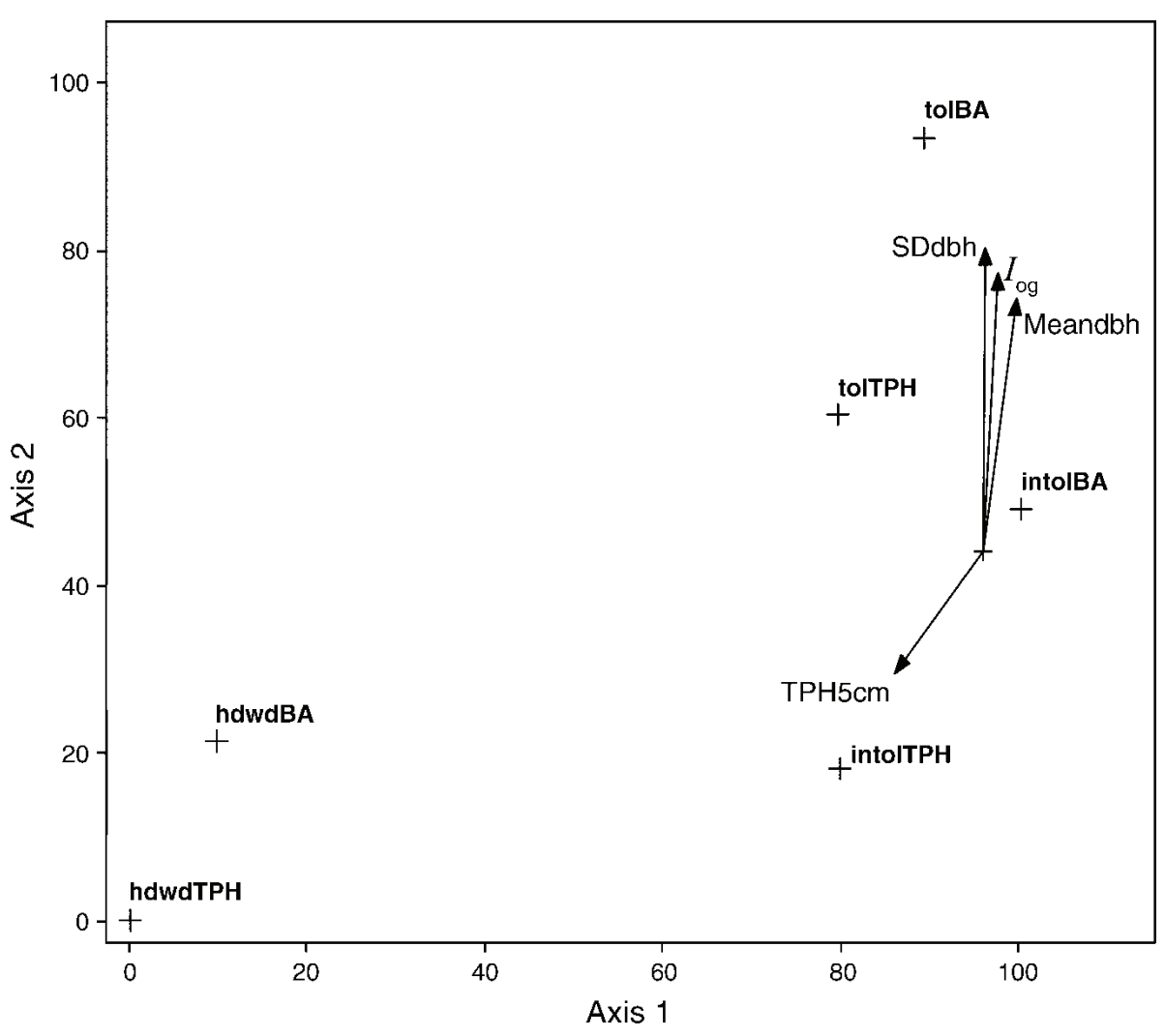

FIG. 7. Nonmetric multidimensional scaling ordination of species composition throughout the study period. Location in ordination space (in boldface type) of hardwood density, in trees per hectare (hdwdTPH), hardwood basal area (hdwdBA), shadeintolerant density (intolTPH), shade-intolerant basal area (intolBA), shade-tolerant density (tolTPH), and shade-tolerant basal area (tolBA) is plotted, along with the correlations to the numeric values giving rise to the $I_{\text {og }}$ subscores (mean dbh, standard deviation of dbh (SDdbh), TPH for trees $>5 \mathrm{~cm}$ dbh $(\mathrm{TPH} 5 \mathrm{~cm})$; TPH for trees $>100 \mathrm{~cm}$ dbh not shown) and the calculated composite $I_{\text {og }}$ score (TPH, no. trees/ha).

probability of mortality has been shown to be positively related to potential site productivity (Bi 2001, Eid and Tuhus 2001, Shen et al. 2001, Yao et al. 2001). The increased probability of mortality is a consequence of the higher rate of biomass accumulation on higher productivity sites, which is in turn associated with a more quickly decreasing stem density according to the self-thinning relationship (Yoda et al. 1963). Elevated rates of competitive mortality on high-productivity sites decrease the duration of the competitive exclusion phase of stand development, allowing later stages characterized by relatively greater structural complexity to be reached in a shorter period of time.

Episodic noncompetitive tree mortality in the overstory results in growth increases of understory shadetolerant trees (Winter et al. 2002), which promotes recruitment from the seedling $(<5 \mathrm{~cm}$ dbh $)$ size class to the tree $(>5 \mathrm{~cm})$ size class in canopy gaps (Stewart 1986). Recruitment of shade-tolerant conifers into the tree size class increases within-stand variation in tree diameter (Huff 1995, Zenner 2005), which corresponds with increasing $I_{\mathrm{og}}$ scores (Fig. 4). Rates of shadetolerant tree recruitment should be elevated on highproductivity sites compared to low-productivity sites given similar rates of non-competitive overstory tree mortality across the productivity gradient; noncompetitive mortality is likely to have variable relationships with productivity depending on species, location, age, and the specific agent of mortality (Franklin et al. 1987). Canopy gaps large enough to influence shade-tolerant tree recruitment develop in a shorter period of time on high-productivity sites because trees attain large size relatively faster on high-productivity sites. This same mechanism is consistent with the observation of Franklin et al. (2002) that spatial heterogeneity due to gap creation develops more rapidly on high-productivity sites.

\section{Management Implications}

Currently, a common management objective on many public and some private lands is to develop and maintain structurally complex late-successional forests in landscapes formerly managed for timber production. Active silvicultural treatments, sometimes termed "restoration," are increasingly utilized in young, previously harvested stands to hasten forest structural development (Spies et al. 1991, Carey 2003, Keeton 2006, Davis et al. 2007, Deal 2007). 
Site productivity is an important consideration in prioritizing young, previously harvested stands for restoration treatments. Stands on low-productivity sites move through the developmental sequence at a relatively slow pace. Therefore, where reserve-wide reestablishment of structurally complex forests is the primary objective (e.g., City of Seattle 2000) but budgets are limiting, low-productivity sites may have the highest priority for restoration treatments. High-productivity sites should respond rapidly to restoration treatments, producing structurally complex forests in the shortest time. Hence, stands on high-productivity sites may take priority for treatment if the primary objective is restoration of complex structure on a portion of a large management area, for example to provide critical habitat for species of concern.

In many temperate forest ecosystems only small areas of structurally complex forest remain. As a result, conservation reserves are established in previously harvested forests (for example, Late-successional Reserves in the Northwest Forest Plan [USDA and USDI 1994]) so that the desired conditions and associated biodiversity can be created and sustained, respectively, in the future. Results from this study suggest that preserving more productive areas within forest landscapes will yield complex forest structure in a shorter time period. Thus, the productive capacity of forest lands should be considered when designating new reserves, in addition to reserve spatial arrangement and extent. Within the Douglas-fir region variation in site class (Isaac 1949) will be a useful guide for designating new areas to be managed for development of structurally complex forests. More generally, when conservation reserves are designated to allow for the future development of desired habitats, the capacity of the site to develop the desired condition should be included in reserve design and site selection.

\section{ACKNOWLEDGMENTS}

The National Science Foundation, Wind River Canopy Crane Research Facility, and the Seattle ARCS Foundation (Burdette and John McClelland Fellowship) provided funding support. We thank the past and current managers of the Cedar River Municipal Watershed (Seattle Public Utilities) for initiating and maintaining this permanent plot study. Comments by D. J. Churchill, J. A. Freund, K. N. Johnson, V. R. Kane, R. T. Paine, T. A. Spies, L. E. Winter, and two anonymous reviewers improved earlier drafts of this article.

\section{Literature Cited}

Acker, S. A., T. E. Sabin, L. M. Ganio, and W. A. McKee. 1998. Development of old-growth structure and timber volume growth trends in maturing Douglas-fir stands. Forest Ecology and Management 104:265-280.

Agrawal, A. A., et al. 2007. Filling key gaps in population and community ecology. Frontiers in Ecology and the Environment 5:145-152.

Barg, A. K., and R. L. Edmonds. 1999. Influence of partial cutting on site microclimate, soil nitrogen dynamics, and microbial biomass in Douglas-fir stands in western Washington. Canadian Journal of Forest Research 29:705-713.
Bi, H. 2001. The self-thinning surface. Forest Science 47:361370.

Bible, K. J. 2001. Long-term patterns of Douglas-fir and western hemlock mortality in the western Cascade Mountains of Washington and Oregon. Dissertation. University of Washington, Seattle, Washington, USA.

Carey, A. B. 2003. Biocomplexity and restoration of biodiversity in temperate coniferous forest: inducing spatial heterogeneity with variable-density thinning. Forestry 76:127-136.

Carey, A. B., and R. O. Curtis. 1996. Conservation of biodiversity: a useful paradigm for forest ecosystem management. Wildlife Society Bulletin 24:610-620.

City of Seattle. 2000. Final Cedar River Watershed Habitat Conservation Plan. Seattle, Washington, USA.

Connell, J. H., and R. O. Slatyer. 1977. Mechanisms of succession in natural communities and their role in community stability and organization. American Naturalist 111: 1119-1144.

Davis, L. R., K. J. Puettmann, and G. F. Tucker. 2007. Overstory response to alternative thinning treatments in Douglas-fir forests of western Oregon. Northwest Science 81: $1-14$.

Deal, R. L. 2007. Management strategies to increase stand structural diversity and enhance biodiversity in coastal rainforests of Alaska. Biological Conservation 137:520-532.

Deal, R. L., P. E. Hennon, E. H. Orlikowska, and D. V. D'Amore. 2004. Stand dynamics of mixed red alder-conifer forests of southeast Alaska. Canadian Journal of Forest Research 34:969-980.

Eid, T., and E. Tuhus. 2001. Models for individual tree mortality in Norway. Forest Ecology and Management 154: 69-84.

Franklin, J. F., and C. T. Dyrness. 1988. Natural vegetation of Oregon and Washington. Oregon State University Press, Corvallis, Oregon, USA.

Franklin, J. F., and M. A. Hemstrom. 1981. Aspects of succession in the coniferous forests of the Pacific Northwest. Pages 212-229 in D. C. West, H. H. Shugart, and D. B. Botkin, editors. Forest succession. Springer-Verlag, New York, New York, USA.

Franklin, J. F., and J. A. MacMahon. 2000. Messages from a mountain. Science 288:1183-1185.

Franklin, J. F., H. H. Shugart, and M. E. Harmon. 1987. Tree death as an ecological process. BioScience 37:550-556.

Franklin, J. F., and T. A. Spies. 1991. Ecological definitions of old-growth Douglas-fir forests. Pages 61-69 in L. F. Ruggeri, K. B. Aubry, A. B. Carey, and M. H. Huff, technical coordinators. Wildlife and vegetation of unmanaged Douglas-fir forests. General Technical Report PNW-GTR-285. USDA Forest Service, Portland, Oregon, USA.

Franklin, J. F., T. A. Spies, R. Van Pelt, A. B. Carey, D. A. Thornburgh, D. R. Berg, D. B. Lindenmayer, M. E. Harmon, W. S. Keeton, D. C. Shaw, K. Bible, and J. Chen. 2002. Disturbances and structural development of natural forest ecosystems with silvicultural implications, using Douglas-fir forests as an example. Forest Ecology and Management 155:399-423.

Franklin, J. F., and R. Van Pelt. 2004. Spatial aspects of structural complexity in old- growth forests. Journal of Forestry 102:22-28.

Gara, R. I., W. R. Littke, J. K. Agee, D. R. Geiszler, J. D. Stuart, and C. H. Driver. 1985. Influence of fires, fungi, and mountain pine beetles on development of a lodgepole pine forest in south-central Oregon. Pages 153-162 in D. M. Baumgartner, editor. Lodgepole pine: the species and its management. Washington State University Conferences and Institutes, Pullman, Washington, USA.

Goldin, A. 1992. Soil survey of Snoqualmie Pass area, parts of King and Pierce Counties, Washington. USDA Soil Conservation Service, Washington, D.C., USA. 
Halpern, C. B. 1988. Early-successional pathways and the resistance and resilience of forest communities. Ecology 69: $1703-1715$.

Huff, M. H. 1995. Forest age structure and development following wildfires in the western Olympic Mountains, Washington. Ecological Applications 5:471-483.

Isaac, L. A. 1943. Reproductive habits of Douglas-fir. Charles Lathrop Pack Forestry Foundation, Washington, D.C., USA.

Isaac, L. A. 1949. Better Douglas-fir from better seed. University of Washington Press, Seattle, Washington, USA

Jenkins, D. H., D. A. Devlin, N. C. Johnson, and S. P. Orndorff. 2004. System design and management for restoring Penn's woods. Journal of Forestry 102:30-36.

Keeton, W. S. 2006. Managing for late-successional/old-growth characteristics in northern hardwood-conifer forests. Forest Ecology and Management 235:129-142.

Keeton, W. S., and J. F. Franklin. 2005. Do remnant oldgrowth trees accelerate rates of succession in mature Douglas-fir forests? Ecological Monographs 75:103-118.

King, J. E. 1966. Site index curves for Douglas-fir in the Pacific Northwest. Weyerhaeuser Forestry Paper No. 8. Weyerhaeuser, Centralia, Washington, USA.

Kruskal, J. B. 1964. Nonmetric multidimensional scaling: a numerical method. Psychometrika 29:115-129.

Larson, A. J., and J. F. Franklin. 2005. Patterns of conifer tree regeneration following an autumn wildfire event in the western Oregon Cascade Range, USA. Forest Ecology and Management 218:25-36.

Larson, A. J., and R. T. Paine. 2007. Ungulate herbivory: indirect effects cascade into the treetops. Proceedings of the National Academy of Sciences (USA) 104:5-6.

Lindenmayer, D. B., and J. F. Franklin. 2002. Conserving forest biodiversity. Island Press, Washington, D.C., USA.

Lindenmayer, D. B., J. F. Franklin, and J. Fischer. 2006. General management principles and a checklist of strategies to guide forest biodiversity conservation. Biological Conservation 131:433-445.

Lutz, J. A., and C. B. Halpern. 2006. Tree mortality during early forest development: a long-term study of rates, causes and consequences. Ecological Monographs 76:257-275.

Morris, E. C., and P. J. Myerscough. 1991. Self-thinning and competition intensity over a gradient of nutrient availability. Journal of Ecology 79:903-923.

Oliver, C. D., and B. C. Larson. 1996. Forest Stand Dynamics. John Wiley and Sons, New York, New York, USA.

Pringle, R. M., T. P. Young, D. I. Rubenstein, and D. J. McCauley. 2007. Herbivore-initiated interaction cascades and their modulation by productivity in an African savanna. Proceedings of the National Academy of Sciences (USA) 104 193-197.

Shen, G., J. A. Moore, and C. R. Hatch. 2001. The effect of nitrogen fertilization, rock type, and habitat type on individual tree mortality. Forest Science 47:203-213.

Spies, T. A. 2004. Ecological concepts and diversity of oldgrowth forests. Journal of Forestry 102:14-20.
Spies, T. A., and J. F. Franklin. 1988. Old growth and forest dynamics in the Douglas-fir region of western Oregon and Washington. Natural Areas Journal 8:190-201.

Spies, T. A., and J. F. Franklin. 1991. The structure of natural young, mature, and old- growth Douglas-fir forests in Oregon and Washington. Pages 90-109 in L. F. Ruggeri, K. B. Aubry, A. B. Carey, and M. H. Huff, technical coordinators. Wildlife and vegetation of unmanaged Douglas-fir forests. General Technical Report PNW-GTR-285. USDA Forest Service, Portland, Oregon, USA

Spies, T. A., J. Tappeiner, J. Pojar, and D. Coates. 1991. Trends in ecosystem management at the stand level. Pages 628-639 in Transactions of the 56th North American Wildlife and Natural Resources Conference. Wildlife Management Institute, Washington, D.C., USA.

Steiner, C. F., Z. T. Long, J. A. Krumins, and P. J. Morin. 2006. Population and community resilience in multitrophic communities. Ecology 87:996-1007.

Stewart, G. H. 1986. Population dynamics of a montane conifer forest, western Cascade Range, Oregon, USA. Ecology 67: $534-544$.

Stuart, J. D., J. K. Agee, and R. I. Gara. 1989. Lodgepole pine regeneration in an old, self-perpetuating forest in south central Oregon. Canadian Journal of Forest Research 19: 1096-1104.

USDA and USDI. 1994. Record of decision on management of the habitat for late-successional and old-growth forest related species within the range of the northern spotted owl (Northwest Forest Plan). U.S. Department of Agriculture and U.S. Department of the Interior, Portland, Oregon, USA.

Van Pelt, R., and N. M. Nadkarni. 2004. Development of canopy structure in Pseudotsuga menziesii forests in the southern Washington Cascades. Forest Science 50:326-341.

Winter, L. E., L. B. Brubaker, J. F. Franklin, E. A. Miller, and D. Q. DeWitt. 2002. Canopy disturbances over the fivecentury lifetime of an old-growth Douglas-fir stand in the Pacific Northwest. Canadian Journal of Forest Research 32: 1057-1070.

Yao, X., S. J. Titus, and S. E. MacDonald. 2001. A generalized logistic model of individual tree mortality for aspen, white spruce, and lodgepole pine in Alberta mixedwood forests. Canadian Journal of Forest Research 31:283-291.

Yoda, K., T. Kira, H. Ogawa, and K. Hozumi. 1963. Selfthinning in overcrowded pure stands under cultivated and natural conditions (intraspecific competition among higher plants). Journal of Biology Osaka City University 14:107129.

Zenner, E. K. 2004. Does old-growth condition imply high livetree structural complexity? Forest Ecology and Management 195:243-258.

Zenner, E. K. 2005. Development of tree size distributions in Douglas-fir forests under differing disturbance regimes. Ecological Applications 15:701-714. 